Dialectologia 22 (2019), 17-29.

ISSN: 2013-2247

Received 15 February 2017.

Accepted 17 September 2017.

\title{
THE INFLUENCE OF STANDARD BASQUE IN BUSTURIALDEA. \\ PART 1: DEMONSTRATIVE PRONOUNS ${ }^{1}$
}

\author{
Ariane EnSUNZA AlDAMIZETXEBARRIA \\ Universidad del País Vasco (UPV/EHU)* \\ ariane.ensunza@ehu.eus
}

\begin{abstract}
This work presents the influence of Standard Basque in the position of the demonstratives in the Basque variety spoken in Busturialdea. It is a diatopic and sociolinguistic research as it shows the syntactic differentiation between elder (60-80) and youth (20-30) from 20 localities.

Data for this research was taken from a more exhaustive PhD research where the linguistic variation from these 20 localities was investigated. A questionnaire was prepared to collect different parts of language such as morphology, phonology, lexicon and syntax and 100 questions were done to 2 informants in each locality.

This paper is focused in (hau) variable, exactly in the change between generations according to the position of the demonstrative pronouns. The influence of Standard Basque on vernacular is evident, but this change is happening further and faster than what it was expected.
\end{abstract}

\section{Keywords}

demonstratives, variation, change, levelling, Basque

\footnotetext{
${ }^{1}$ This research has been done by the programme of the Basque Government called Ikertzaileak prestatzeko eta hobetzeko laguntzen programa of "programme of helping to form and develop researchers" (code BFI-2010-253).

* Escuela de Ingeniería de Bilbao, Ingeniero Torres Quevedo Plaza, №1, 48013 Bilbo, Bizkaia.
} 


\section{LA INFLUENCIA DEL VASCO ESTÁNDAR EN BUSTURIALDEA. PARTE 1: PRONOMBRES DEMOSTRATIVOS}

\section{Resumen}

Esta contribución presenta la influencia del vasco estándar en la posición de los pronombres demostrativos del vasco hablado en Busturialdea. Es una investigación diatópica y sociolingüística, ya que muestra la diferenciación sintáctica entre mayores (60-80 años) y jóvenes (20-30 años) de 20 localidades.

Los datos utilizados son parte de una tesis doctoral en la que se estudia exhaustivamente la variación lingüística de estas 20 localidades. Se realizaron 100 preguntas mediante un cuestionario que se preparó para recoger diversos aspectos del lenguaje como morfología, fonología, léxico y sintaxis. Dicho cuestionario lo respondieron dos personas de cada localidad.

El presente trabajo está focalizado en la variable (hau); más exactamente, en el cambio de posición de los pronombres personales entre generaciones. Es evidente la influencia que ha ejercido, y está ejerciendo, el vasco estándar en las hablas vascas, pero esta influencia es mayor y más rápido de lo que se pensaba.

\section{Palabras clave}

demostrativos, variación, cambio, vasco

\section{Introduction}

There have been 250 years since Luis Lucien Bonaparte (1866) made the first Basque dialect classification. About twenty years ago, in 1998, Zuazo provided another dialectal classification of Basque and the last one in 2014. Further from that, Gotzon Aurrekoetxea and Iñaki Gaminde developed the program DiaTech, which displays quantitatively and qualitatively dialectal divergences and gives to the researcher the chance to determine in how many groups the varieties are derived. Nevertheless, it has always existed the disputation about the differentiation between idiolect-dialectlanguage and the tools to measure it. Moreover, Basque, as any other living language, is changing nowadays and Standard Basque is motivating and influencing on it.

Creating and implanting unified Basque is one of the most important steps that Basque language has made in the last decade. On the one hand, it has given to speakers of different dialects the chance to understand each other. On the other hand, it has promoted the levelling of speeches and dialects, as they are closer one from the others nowadays. Basque from all the geography of the Basque Country is getting closer and 
closer and lots of researches have been done to analyze how is this change happening and to give evidence of the linguistic levelling (Ariztimuño 2009; Aurrekoetxea 2003, 2004, 2005, 2006, 2008, 2009, 2012; Ensunza 2012, 2015, 2016; Gaminde 2007, 2010a, 2010b; Gaminde \& Romero 2011; Gaminde, Romero \& Legarra 2012; Unamuno, Ensunza \& Ormaetxea 2012); Unamuno, Ensunza \& Ormaetxea 2012). As these works have shown the influence of Standard Basque in dialects is notable and, moreover, it can be said that it is increasing in youth generations. Probably no so far new dialect classifications should be done.

Data $^{2}$ from this research was collected by a questionnaire prepared to gather different parts of language such as morphology, phonology, lexicon and syntax and we have made 100 questions to 2 informants of each locality. But in this work, we have focused on one specific variable that we have called "(hau) variable" so we are going to present the influence of Standard Basque in the position of the demonstratives in the Basque variety spoken in Busturialdea. We are going to show the differentiation between elder (60-80) and youth (20-30) from 20 localities, all female.

\section{Demonstrative pronouns in Basque ${ }^{3}$}

As many other languages, Basque has a three-term demonstrative system which includes a middle term in addition to the proximal and distal forms and each of the grades has a singular and a plural form. The middle terms "refers to a location in medial or non-proximal distance relative to the deictic center" (Diessel 1999: 39). Table 1 contains the demonstrative forms in Standard Basque:

\footnotetext{
2 In this study we are going to give data from the wider PhD research we defended in 2015.

3 Taken from Ensunza (2015: 95-97; 143).
} 


\section{Demonstrative pronouns}

\begin{tabular}{|l|l|l|}
\hline \multicolumn{1}{|c|}{ Singular } & \multicolumn{1}{|c|}{ Plural } \\
\hline Ordinary & $\begin{array}{l}\text { hau 'this' } \\
\text { hori 'that (near hearer, general)' } \\
\text { hura 'yon ' (in the distance, not present)' }\end{array}$ & $\begin{array}{l}\text { hauek 'these' } \\
\text { horiek 'those (near hearer, general)' } \\
\text { haiek 'yon (in the distance, not present)' }\end{array}$
\end{tabular}

Table 1. Demonstrative pronouns in Basque

In most of the varieties of Basque this demonstrative word follows the noun ('mutil hauek', NOUN-DEM.PL.), but in Biscayan varieties the demonstrative precedes the noun ('honek mutilek', DEM.PL-NOUN.PL). Moreover, as Martinez (2013: 296) says, "in Biscayan there is a pleonastic demonstrative construction consisting of 'demonstrative + NP + suffixed article/ demonstrative' such as "honek mutilek". Constructions like these appear from the beginning of the written tradition in Biscayan (e.g., VJ. oneek amar Mandamientu-ok 'these ten Commandments'). Rather than being an archaic feature, such constructions appear to be a means of creating new demonstratives, once the original suffixed demonstratives have lost some of their deictic force, when they are clitized to the NP modified by them (a tendency particularly strong in westerns dialects). Hence, they may be an old innovation.

It is well documented that in western varieties of Basque the demonstrative goes before the NP:

Onék mutillek guzurre esan deu

Standard: 'Mutil honek gezurra esan du';

DEM. SNG.ERG-NOUN.SNG.ERG.-OBJ.SNG-TRVERB-AUX. SNG NOUN.SNG-DEM. SNG.ERG-OBJ.SNG-TRVERB-AUX. SNG

\section{Ori liburue loi dau}

DEM. SNG.ABS-NOUN.SNG.ABS.-ADJ.SNG-INTRVERB-AUX.SNG
Standard 'Liburu hori zikin dago'.

NOUN.SNG-DEM. SNG.ABS-ADJ.SNG-INTRVERB-AUX.SNG

Other western varieties use the variant demonstrative+NP+demonstrative structure, for example, in Bedarona: au liburuau, au alkondariau, onek mutillok, onek neskok, orrek mutillok, orrek plater guztixok, oneri mutilloneri, ori kaliori, ori mutillori, ori ur botilliori, ori ensaladiori, ori liburuori... We can find this kind of structures also in Nabarniz and Busturia, but not with all the demonstratives: onek mutillok, au liburuau, ori mutillori; but oneri mutilleri, arek gixonak. 
According to Gaminde (2007: 95), the position of the demonstrative is determined by its function and, thus, when the demonstrative is deictic, we will find the demonstrative $+N P+$ demonstrative structure, such as in Bedarona. On the other hand, Gaminde points out that before the NP we can find any demonstrative, but after the NP only the article (-a). Nevertheless, in our data we have gathered examples of demonstrative that go after the NP not being just an article:

- A este chico le han mentido 'This boy has beeb lied to'

Mutill oneri gusurre esan dotzie (Muxika elder)

Mutill oneri gusurre esan dotzoe (Mundaka elder)

Mutil oneri gusurre esantze (Nabarniz youth)

- Estos chicos están cansados 'These boys are tired'

Mutiy onek kantzeta daus (Muxika youth)

Mutiy auek kantsaute dauz (Nabarniz youth)

- Aquel hombre ha robado dos libros 'This man has stolen two books'

Gixon arek bi liburu ostu deus (Muxika youth)

Gaminde (2007) points out that in this varieties when the noun is referential (mentioned before), the demonstrative can go after the noun. So, we can think that the informant is making reference to "that thing that I mentioned in my question when making the interview". Nevertheless, it is not a causality that most of the examples gathered are those from the youngest generations; in fact, with the influence of standard Basque it is increasing the use of the demonstrative after the noun and that is why youth use that structure even when the noun is not referential. Moreover, if we look at the free conversations recorded with each informant, this data can be corroborated.

In Busturialdea, this innovation has different geographical distribution, so it is interesting to analyze the two variants of (hau) variable: demonstrative $+N P$ (in this research (hau+l)) and NP+ demonstrative (in this research (I+hau)).

These are some of the questions and answers gathered to research (hau) variable: 
- Ese bolígrafo está gastado 'That pen is spent'

Ori boligrafu gastata deu (Elantxobe youth)

DEMONSTRATIVE.SNG+NOUN.SNG

Boligrafo ori gastata dau (Sukarrieta youth)

NOUN.SNG+DEMONSTRATIVE.SNG

- Este libro está sucio 'This book is dirty'

Au librue loi dau (Morga youth)

DEMONSTRATIVE.SNG+NOUN.SNG

Liburu au sikiñe dau (Nabarniz youth)

NOUN+DEMONSTRATIVE.SNG

- Si llevo todos esos platos, se me van a caer 'If I carry all those plates, they will fall'

Orrek plater gustixek badaroatesen, jeusi engo yates (Kortezubi youth)

DEMONSTRATIVE.PL+NOUN+ALL.PL

Plater orrek gustisek eruten batesen, jeusi engo dastes (Gautegiz-Arteaga youth)

NOUN+DEMONSTRATIVE.PL+ALL.PL

Plater gusti orrek eruten badotas, jeusi engo xates (Nabarniz youth)

NOUN+ALL+DEMONSTRATIVE.PL

- No se si a Josu le va a quedar bien esta camisa 'I do not know if this shirt will fit Josu'

Estakitz Yosuri ondo geratuko bayako au arkondarie (Forua youth)

DEMONSTRATIVE.SNG+NOUN.SNG

Estakitx Yosuri arkondara au ondo lotuko badatzon (Sukarrieta youth)

NOUN+DEMONSTRATIVE.SNG

- Si veo esa película, me van a entrar ganas de llorar 'If I see that film I will cry'

Ori pelikuli kusten badot, negarguri sartungo dast (Elantxobe youth)

DEMONSTRATIVE.SNG+NOUN

Pelikula ori ikusten badot, negar eitxeko gogue zartuko yat (Busturia youth)

NOUN+DEMONSTRATIVE.SNG

- Ese balde es demasiado pequeño 'That pail is too small'

Ori baldi txikixeixe da (Elantxobe elder)

DEMONSTRATIVE.SNG+NOUN

Balde ori lar txikixeixe da (Mundaka youth)

NOUN+DEMONSTRATIVE.SNG 
Dialectologia 22 (2019), 17-29.

ISSN: 2013-2247

- Esas chicas han hecho un buen trabajo 'Those girls made a good job'

Orrek neskak biar ona ein dabe (Elantxobe elder)

DEMONSTRATIVE.SNG+NOUN

Neska orrek lan ona ein dabe (Muxika youth)

NOUN+DEMONSTRATIVE.PL

- He pensado que ese chico era el primo de Ane 'I thought that boy was Ane's cousin'

Pentze ot base, ori mutille Anen lengusu dala (Nabarniz elder)

DEMONSTRATIVE.SNG+NOUN

Pentze dot mutiy ori Anen lengusue dala (Gernika-Lumo youth)

NOUN+DEMONSTRATIVE.SNG

- Se puede pensar que ese pez está muerto 'It can be thought that that fish is dead'

Esan leike base, ori arrañe illye dauela (Gautegiz-Arteaga elder)

DEMONSTRATIVE.SNG+NOUN

Pentze leike arraiñ ori ilde dauela (Gautegiz-Arteaga youth)

NOUN+DEMONSTRATIVE.SNG

- Esa ensalada está hecha con verduras ecológicas 'That salad is made with ecologic vegetables'

Ori ensaladie dau eñye berdura ekolojikukin (Ereño youth)

DEMONSTRATIVE.SNG+NOUN

Ensalada ori berdura ekolojikoakas eñye dau (Gernika-Lumo youth)

NOUN+DEMONSTRATIVE.SNG

\section{Geolinguistic and sociolinguistic analysis ${ }^{4}$}

In this section we are presenting a quantitative analysis of the data gathered. We have used a program called DiaTech to depict the geographical distribution of each variant and make the analysis. In this way, we are going to research the geolinguistic and sociolinguistic distribution of the variable (hau), as we are going to present the difference between youth and elder speech to compare one with the other and see the evolution of this variable.

Map 1 presents the geographical distribution of elder taking into account the (hau) variable. Map 2 presents the geographical distribution of youth.

\footnotetext{
${ }^{4}$ Taken from Ensunza (2015: 129-130; 143).
} 

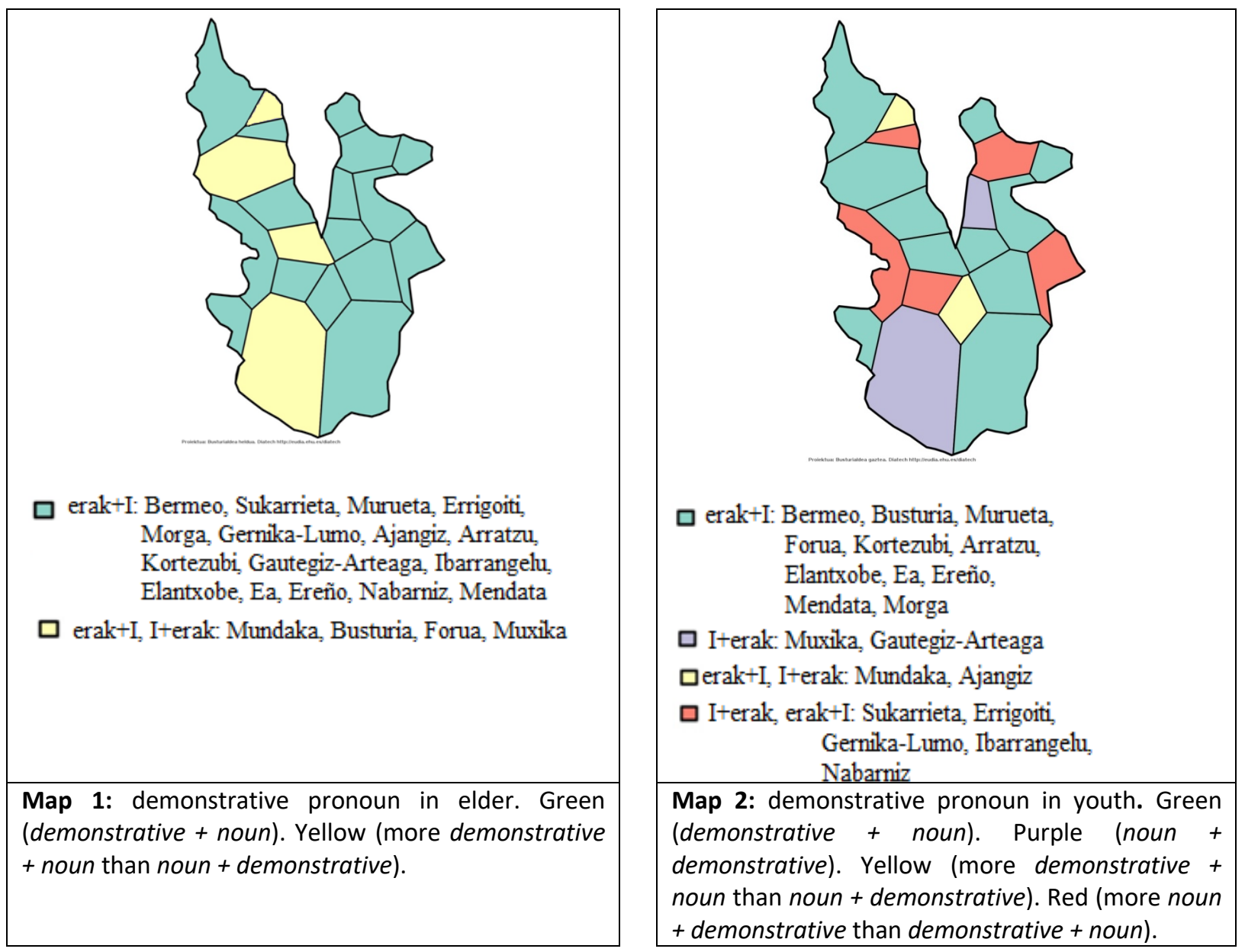

As we can observe in Map 1, most of the Busturialdea speech use the variant $($ erak $+\mathrm{l})$, that is, elder use the demonstrative before the NP (green), as it has been the frequent structure for it since nowadays in western varieties. Nevertheless, we can see that some of elder speech present the (I+erak) structure by the time we made the research. Mundaka, Busturia, Forua and Muxika do have the presence of the new structure $N P+$ demonstrative (yellow). It must be pointed out that the presence of the new structure appears in elder speech but usually mixed with the old structure, so we can see that change is still in progress.

Nevertheless, as we can observe in Map 2 the speech of youth has suffered a notable change in (hau) variable. The old (erak+l) structure that was characteristic of western varieties (green) is losing its strength and the new (I+erak) structure has taken its place in youth vernacular (purple, red and yellow). Moreover, in Muxika and 
Gautegiz-Arteaga the new structure is the only one that is used (purple) so the change has finalized in these localities.

The old structure has been best preserved in 9 localities: Bermeo, Murueta, Kortezubi, Arratzu, Elantxobe, Ea, Ereño, Mendata and Morga. On the other hand, Busturia and Forua changed from the new variant to the old one in youth vernacular and now is more used the old (erak+l) structure, being the only one that is used.

The conclusion taken from the geolinguistic analysis is that our hypothesis was correct: standard Basque has influenced the use of $N P+$ demonstrative structure in western varieties and in youth vernacular it has introduced with strength. Due to this influence, the variant that was characteristic of western varieties is losing quickly.

\section{Statistical analysis: age variable ${ }^{5}$}

In this section we analyze the use of each variant that (hau) variable has; we compare the change that has suffered from elder speech to youth speech by showing how often do one and others use each variant and we compare the use of them.

Graphic 1 shows the percentage of each variant in elder speech and graphic 2 shows the percentage of youth:

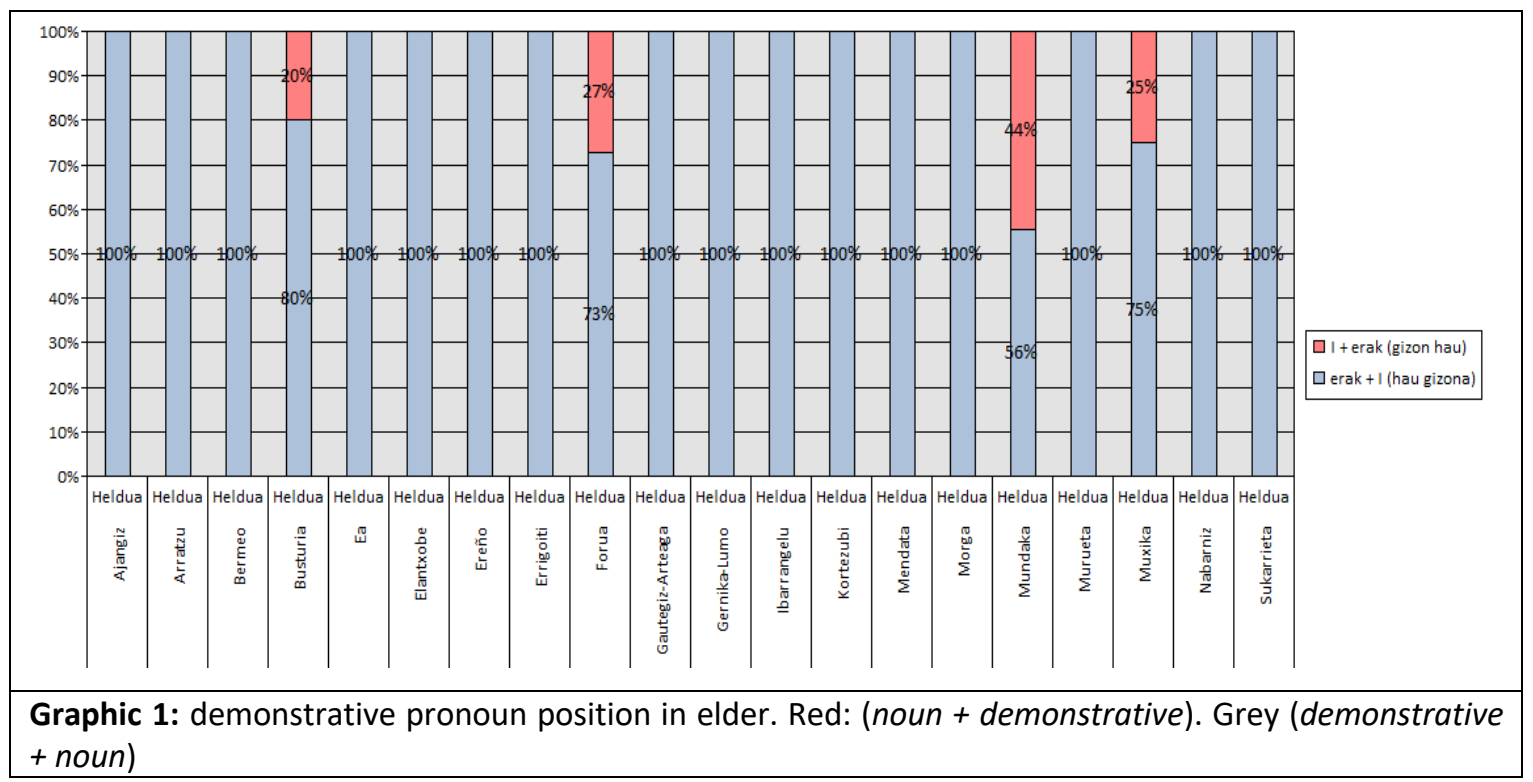

\footnotetext{
${ }^{5}$ Taken from Ensunza (2015: 186-188; 193).
} 


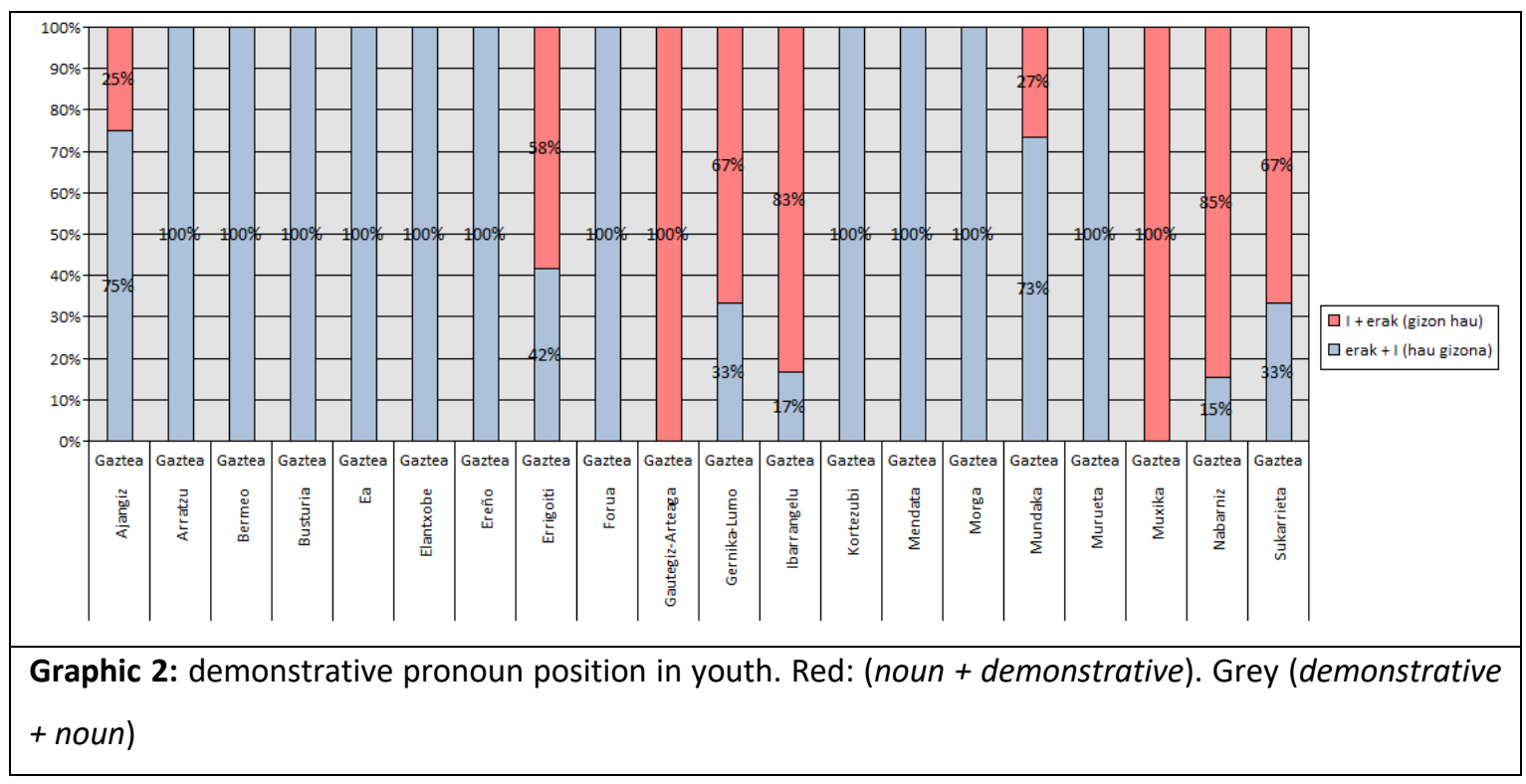

As it is shown in graphic 1 there are 4 localities that show variation in elder speech: Busturia, Forua, Mundaka and Muxika. Nevertheless, in all the localities the predominant variant is (erak+l), that is, the demonstrative goes before the NP (grey); in Busturia it is used in $80 \%$ of the cases, in Forua $73 \%$, in Muxika $75 \%$ and in Mundaka $56 \%$.

On the other hand, as graphic 2 shows, in youth speech the variation is more notable and the new (I+erak) variant is the predominant (red), that is, the demonstrative goes after the NP in most of the cases. The structure that in elder speech was unknown in Errigoiti, youth use 58\% of the cases, in Gernika-Lumo 67\%, in Ibarrangelu 83\%, in Sukarrieta 67\%, in Nabarniz 85\% and in Ajangiz 25\%. Moreover, in some localities where the new structure was used rarely in elder speech, increased in the speech of youth: in Muxika from 25\% to $100 \%$ (+75\%).

Nevertheless, it is no surprising the increase of the use of the new variant in vernacular speech as this is the only structure that is taught in education and, so, the only one that youth learn at school.

According to the statistical analysis made with SPSS, the change that (hau) variable undergoes in age is statistically significant $(U=(Z=-2,081) 136,000 ; p<* 0,038)$ : 


\begin{tabular}{|rc|r|r|r|}
\hline \multicolumn{1}{|c|}{ Rangos } \\
\hline \multirow{2}{*}{ emaitza } & adina & N & Rango promedio & Suma de rangos \\
& 1,00 & 20 & 23,70 & 474,00 \\
& 2,00 & 20 & 17,30 & 346,00 \\
& Total & 40 & & \\
\hline
\end{tabular}

\begin{tabular}{|c|c|}
\hline \multicolumn{2}{|c|}{ Estadísticos de pruebaa } \\
\hline & emaitza \\
\hline U de Mann-Whitney & 136,000 \\
\hline W de Wilcoxon & 346,000 \\
\hline Z & $-2,081$ \\
\hline Sig. asintótica (bilateral) &, 037 \\
\hline $\begin{array}{l}\text { Significación exacta [2*(sig. } \\
\text { unilateral)] }\end{array}$ &, $086^{\mathrm{b}}$ \\
\hline
\end{tabular}

a. Variable de agrupación: adina

b. No corregido para empates.

We can conclude that the statistical analysis shows that the change of (hau) variable is statistically significant in the different generations in the 20 localities of Busturialdea. In fact, in elder speech (erak+l) or demonstrative + NP variant is the predominant structure but in youth speech (I+erak) or NP + demonstrative.

\section{Conclusions}

In this study we have analyzed the influence of Standard Basque in the position of the demonstratives in the Basque variety spoken in Busturialdea. We have presented data collected from elder (60-80) and youth (20-30) from 20 localities, all female.

The geolinguistic analysis show that our hypothesis was correct: standard Basque has influenced the use of $N P+$ demonstrative structure in western varieties and it has introduced with strength in youth vernacular. Due to this influence, the variant that was characteristic of western varieties is losing quickly. In fact, in elder speech the predominant structure is (erak+1) or demonstrative $+N P$ variant but, on the contrary, in youth speech the most used structure is (I+erak) or NP + demonstrative. 
On the other hand, statistical analysis shows that the change of (hau) variable is statistically significant in the different generations in the 20 localities of Busturialdea.

Basque from all the geography of the Basque Country is getting closer and closer, indeed, because Basque, as any other living language, is changing nowadays and Standard Basque is motivating and influencing on it. On the one hand, it has given to speakers of different dialects the chance to understand each other. On the other hand, it has promoted the levelling of speeches and dialects, as they are closer one from the others nowadays. The Basque varieties spoken in Busturialdea are a good example of this linguistic change.

\section{References}

ARIzTIMUÑo, B. (2009) "Tolosako eta Ataungo hizkerak: hizkuntz bariazioa eta konbergentzia joerak", Uztaro 72, 79-96.

AURREKOetXEA, G. (1992) “Nafarroako euskara: azterketa dialektometrikoa”, Uztaro 5, 59-109.

AURREKOETXEA, G. (1995) Bizkaieraren egituraketa geolinguistikoa, Leioa: UPV-EHUko Argitarapen Zerbitzua / Serie Tesis doctorales.

AuRREKoetXEA, G. (2003) "Euskalkiak estandarraren uholdepean (Arratiako kasua)", in Ahozkotasuna aztergai, Mendebalde Kultura Alkartea, 167-185.

AURREKOETXEA, G. (2004) "Estandar eta dialektoen arteko bateratze-joerak (ikuspuntu teorikotik begirada bat)", Uztaro 50, 45-57.

AURREKOETXEA, G. (2005) “Nafarroako euskararen sailkapenaz”, in P. Etxeberria \& H. Knörr (arg.), Nerekin yaio nun. Txillardegiri omenaldia, Iker 17, EHU \& Euskaltzaindia, Bilbo, 109-124.

AURREKOETXEA, G. (2006) "Hizkuntza estandarraren eta dialektoen arteko bateratze joerak", Anuario del Seminario de Filología Vasca Julio Urquijo XL 1-2, 133-160.

AuRrekoetXeA, G. (2008) “Bariazio soziolinguistikoa Dimako euskaran”, Euskalingua 12, 17-26.

AURREKOETXEA, G. (2009) “Iparraldeko hizkeren sailkapena (1): lexikoa”, ASJU XXXVIII-1, 287-331.

AURREKOETXEA, G. (2012) "Towards a scientific measurement of linguistics boundaries", in Álvarez Pérez, Xosé Alfonso, Ernestina Carrilho \& Catarina Magro (arg.), Proceedings of the International Symposium on Limits and Areas in Dialectology (LimiAr). Lisbon, 2011. Lisboa: Centro de Lingüística da Universidade de Lisboa. 
BONAPARTE, L. L. (1863) Carte des sept provinces basques montrant la delimitation actuelle de l'euscara et sa division en dialectes, sous-dialectes et varietes, Standford's Geographical Establishment, London. [Berrarg. [1990], in Opera Omnia Vasconice Bilbo: Euskaltzaindia.]

DIESSEL, H. (1999) “Demonstratives: Form, function and grammaticalization." Typological Studies in Language 42. Amsterdam: John Benjamins.

ENSUNZA, A. (2012) "Gernika-Lumoko euskararen aldakortasuna: aldagai fonetiko zenbait", ASJU XLVI-2, Gasteiz: UPV/EHU, 177-244.

ENSUNZA, A. (2015) Busturialdeko euskararen hizkuntza aldakortasuna denboran eta espazioan, EHUko doktoretza-tesiak.

ENSUNZA, A. (2016) "The sociolinguistic variation of palatalization: the case of Gernika-Lumo", Dialectologia 16, 71-91 < http://www.publicacions.ub.edu/revistes/dialectologia16/>.

GAMINDE, I. (2007) Bizkaian Zehar: Euskararen Ikuspegi Orokorra, Mendebalde Kultura Alkartea eta Bizkaiko Foru Aldundia. Bilbo.

GAMINDE, I. (2010a) Bizkaiko gazteen prosodiaz: euskaraz eta gaztelaniaz. Bilbao: Mendebalde Kultur Alkartea eta Bizkaiko Foru Aldundia.

GAMINDE, I. (2010b) "Bilboko gazte euskaldunen ezaugarri linguistikoez", in Mendebalde Kultura Alkartea: Bilbon Mundua Ikusi, 35-59.

GAMinde, I., \& Romero, A. (2011) "Generoa eta adina Bermeoko berbaldiaren fonemen eta hotsen frekuentzian", Fontes Linguae Vasconum 113: 115-138.

Gaminde, I., A. Romero \& H. LegarRa (2012) Gramatika eta hizkuntza bariazioa Bermeon, Bermeoko Udala: Bermeo.

Martínez Areta, M. (2013) "Demonstratives and Personal Pronouns in Basque and ProtoBasque", Mikroglottika 5, edited by M. Martinez-Areta, Peter Lang, 283-321.

Unamuno, L., Ensunza, A., OrmaetXeA, J.L. (2012) "EAS project: first overview of the syntax variation in the Basque language", in Álvarez Pérez, Xosé Alfonso, Ernestina Carrilho \& Catarina Magro (eds.), Proceedings of the International Symposium on Limits and Areas in Dialectology (LimiAr), Lisbon, 2011, Lisboa: Centro de Lingüística da Universidade de Lisboa, 225-235.

ZUAZO, K. (1998) "Euskalkiak, gaur", Fontes Linguae Vasconum 78, 191-233.

ZUAZO, K. (2014) Euskalkiak, Elkar: Donostia. 